\title{
Faktor yang Berhubungan dengan Gangguan Pendengaran Pekerja di Industri Pengolahan Karet PT. X Kabupaten Seluma Bengkulu
}

\author{
Andriana Marwanto ${ }^{1}$, Mualim mualim ${ }^{2}$ \\ Poltekkes Kemenkes Bengkulu Jurusan Kesehatan Lingkungan \\ andrian.marwanto@gmail.com
}

\begin{abstract}
Abstrak
Kesehatan kerja bertujuan agar pekerja memperoleh derajat kesehatan setinggi-tingginya baik fisik, mental maupun sosial Kebisingan merupakan salah satu masalah kesehatan lingkungan kerja, khususnya terhadap fungsi pendengaran. Gangguan pendengaran akibat bising dipengaruhi oleh beberapa faktor seperti intensitas kebisingan, durasi paparan, area tempat kerja dan penggunaan alat pelindung diri. Tujuan penelitian untuk mengetahui faktor yang berhubungan dengan gangguan pendengaran Pekerja di Industri Pengolahan Karet PT. X Kabupaten Seluma Provinsi Bengkulu. Jenis penelitian ini merupakan diskriptif analitik dengan pendekatan cross sectional. Responden penelitian adalah pekerja di bagian produksi dengan Jumlah 56 pekerja. Data diperoleh dengan cara pengukuran intensitas kebisingan, pemeriksaan gangguan pendengaran dengan alat audiometri serta wawancara dengan kuesioner tentang karakteristik responden dan pemakaian Alat Pelindung Diri. Analisis data dilakukan dengan cara uji Che-Square untuk menentukan hubungan antara variabel dan uji regresi logistik untuk menetukan faktor yang paling beresiko terhadap terjadinya gangguan pendengaran. Hasil penelitian diketahui bahwa 73,20\% responden sudah berumur lebih dari 40 tahun, masa kerja responden lebih dari 20 tahun sebesar 51,80\% sudah bekerja di PT X selama lebih dari 20 tahun; $50 \%$ responden memakai APD pada saat bekerja; dan 64,30\% intensitas kebisingan pada ruang produksi masih dibawah nilai NAB $85 \mathrm{~dB}$. Ada hubungan antara umur, pemakaian APD dan Intensitas Kebisingan terhadap gangguan pendengaran, dengan nilai $\mathrm{p}$-value $(0,050 ; 0,006 ; 0,021)$.
\end{abstract}

Kata Kunci : Kebisingan, APD, Gangguan Pendengaran

\begin{abstract}
Factors Related to Hearing Loss Workers in the Rubber Processing Industry PT. X Kabupaten Seluma Provinsi Bengkulu. Occupational health aims at getting workers to the highest possible level of health both physically, mentally and socially. Noise is one of the health problems of the work environment, especially on hearing function. Hearing loss due to noise is influenced by several factors such as noise intensity, duration of exposure, work area and use of personal protective equipment. The purpose of this study was to determine factors associated with hearing loss in the Rubber Processing Industry PT. X Kabupaten Seluma Provinsi Bengkulu. This type of research is analytic descriptive with cross sectional method. The research respondents were workers in the production division with a total of 56 workers. Data obtained by measuring the intensity of noise, examination of hearing loss with audiometry as well as interviews with questionnaires about the characteristics of respondents and the use of Personal Protective Equipment. Data analysis was performed by using the Che-Square test to determine the relationship between variables and logistic regression tests to determine the factors most at risk for hearing loss. The results showed that $73.20 \%$ of respondents were more than 40 years old, respondents had more than 20 years of service for $51.80 \%$ had worked at PT X for more than 20 years; $50 \%$ of respondents use PPE at work; and $64.30 \%$ the intensity of noise in the production room is
\end{abstract}


still below the $85 \mathrm{~dB}$ NAB value. The conclusion is that there is a relationship between age, use of PPE and Noise Intensity to hearing loss, with p-value $(0.050 ; 0.006 ; 0.021)$

Keywords : Noise, PPE, Hearing Loss

\section{PENDAHULUAN}

Kesehatan merupakan salah satu hak dasar dari manusia dan juga sebagai salah satu faktor yang menentukan kualitas dari sumber daya manusia. Kesehatan dan keselamatan masyarakat pekerja sangat terkait hubungannya dengan kesejahteraan dari pekerja itu sendiri. Perusahaan jelas ingin pekerja sehat, dikarenakan pekerja yang sehat akan menghasilkan pekerjaan yang lebih baik dibandingkan dengan pekerja yang kesehatannya terganggu. Kesehatan kerja merupakan salah satu bidang kesehatan masyarakat yang memfokuskan perhatian pada masyarakat pekerja baik yang berada di sektor formal maupun yang berada di sektor informal. ${ }^{1}$

Kesehatan kerja bertujuan agar pekerja memperoleh derajat kesehatan setinggi-tingginya baik fisik, mental maupun sosial. Tujuan tersebut dapat dicapai dengan usaha preventif, kuratif dan rehabilitatif terhadap penyakit penyakit atau gangguan kesehatan yang diakibatkan oleh faktor pekerjaan, lingkungan kerja serta penyakit umum. Tujuan kesehatan kerja dapat tercapai apabila didukung oleh lingkungan kerja yang memenuhi syaratsyarat kesehatan. ${ }^{1}$

Kebisingan merupakan salah satu masalah kesehatan lingkungan. Bising adalah suara yang tidak dikehendaki yang dapat mengganggu dan atau dapat membahayakan kesehatan. Pengaruh bising pada kesehatan berupa gangguan pendengaran dan gangguan bukan pendengaran ${ }^{1}$. Gangguan pendengaran akibat bising atau Noise Induced Hearing Loss (NIHL) adalah gangguan pendengaran tipe sensorineural yang disebabkan oleh pajanan bising yang cukup keras dalam jangka waktu yang lama, biasanya akibat bising lingkungan kerja ${ }^{2}$.

Berdasarkan data dari WHO tahun 2015 menyebutkan bahwa lebih dari 5\% dari populasi dunia memiliki gangguan pendengaran (328 juta orang dewasa dan 32 juta anak anak) (WHO, 2015). Di Indonesia prevalensi ketulian sebesar $4,6 \%$ atau sebanyak 16 juta orang dan gangguan pendengaan sekitar 16,8\% dari jumlah penduduk Indonesia. ${ }^{3}$

Pajanan kebisingan yang berlebihan adalah salah satu faktor penyebab utama terjadinya gangguan pendengaran di berbagai belahan dunia, berdasarkan Survey dari Multi Center Study (MCS) menyebutkan bahwa pada tahun 2000 terdapat 250 juta penduduk dunia mengalami gangguan pendengaran dan sekitar 50\% nya (75-140 juta) berada di Asia Tenggara, termasuk di Indonesia. Indonesia merupakan salah satu dari empat negara di Asia Tenggara dengan prevalensi gangguan pendengaran cukup tinggi, yakni 4,6\% sementara tiga negara lainnya yakni Sri Lanka $(8,8 \%)$, Myanmar $(8,4 \%)$, dan India $(6,3 \%)$. Menurut studi tersebut prevalensi $4,6 \%$ sudah bisa menjadi referensi bahwa gangguan pendengaran memiliki andil besar dalam menimbulkan masalah sosial di tengah masyarakat.

Gangguan pendengaran dapat menimbulkan sejumlah disabilitas seperti masalah dalam percakapan, terutama di lingkungan yang sulit, dapat memberikan sejumlah besar keluhan. Jenis lain dari disabilitas dapat menurunkan kemampuan untuk mendeteksi, mengidentifikasi dan melokalisasi suara dengan cepat dan tepat. Gangguan pendengaran yang tidak dikoreksi dapat menimbulkan penurunan kualitas hidup, isolasi diri, penurunan kegiatan sosial dan perasaan seperti tidak diikutsertakan, yang dapat meningkatkan prevalensi gejala depresi ${ }^{4}$.

Gangguan pendengaran akibat bising menurut beberapa penelitian dipengaruhi oleh beberapa faktor seperti intensitas kebisingan, durasi paparan, area tempat 
kerja dan penggunaan alat pelindung diri. Kebisingan yang sangat kuat lebih besar dari $90 \mathrm{~dB}$ dapat menyebabkan gangguan fisik pada organ telinga. ${ }^{5}$ Seseorang yang bekerja di lingkungan bising lebih dari lima tahun memiliki kemungkinan lebih besar terkena penyakit tuli syaraf koklea yang tidak dapat disembuhkan. ${ }^{6}$

PT. X merupakan perusahaan yang bergerak dalam bidang perkebunan karet dan pabrik pengolahan yang proses produksinya melibatkan banyak tenaga kerja dan penggunaan mesin industri. Oleh karena itu dapat menimbulkan potensi bahaya dari dalam melaksanakan tugasnya tentu harus di dorong dengan rasa nyaman saat bekerja, terjaganya kesehatan dan terhindar dari berbagai gangguan fisik lainnya.

Berdasarkan survei awal pengukuran titik kebisingan di ruang produksi diperoleh tingkat kebisingan di ruangan produksi sebesar 91,2 dBA. Hal tersebut melebihi Nilai Ambang Batas yang dipersyaratkan yaitu $85 \mathrm{dBA}$. Selain itu, sejumlah pekerja juga tidak menggunakan earplug atau earmuff sebagai alat pelindung diri terhadap kebisingan. Dari 10 pekerja yang diamati, 6 pekerja $(60 \%)$ tidak menggunakan APD pada saat bekerja. Hal tersebut dapat menimbulkan gangguan kesehatan berupa gangguan pendengaran. Saat ini belum ada survei mendalam mengenai data pekerja yang mengalami gangguan pendengaran akibat bising di perusahaan tersebut dan faktor faktor yang mempengaruhinya. Sehingga peneliti tertarik untuk melakukan penelitian "Faktor yang Berhubungan dengan Gangguan Pendengaran Pekerja di Industri Pengolahan Karet PT. X Kabupaten Seluma"

\section{METODE}

\section{Waktu dan Tempat}

Tabel 1. Distribusi Frekuensi Variabel Penelitian Faktor yang Berhubungan dengan Gangguan Pendengaran Pekerja di Industri Pengolahan Karet PT. X Kabupaten Seluma Tahun 2019

\begin{tabular}{|l|l|l|l|l|}
\hline No & Variabel Penelitian & Kategori & Frekuensi (f) & Persentase (\%) \\
\hline
\end{tabular}




\begin{tabular}{|c|c|c|c|c|}
\hline \multirow[t]{2}{*}{1} & \multirow[t]{2}{*}{ Umur Responden } & $\geq 40$ Tahun & 41 & 73,20 \\
\hline & & $<40$ Tahun & 15 & 26,80 \\
\hline \multirow[t]{2}{*}{2.} & \multirow{2}{*}{$\begin{array}{l}\text { Masa Kerja } \\
\text { Responden }\end{array}$} & $\geq 20$ Tahun & 29 & 51,80 \\
\hline & & $<20$ Tahun & 27 & 48,20 \\
\hline \multirow[t]{2}{*}{3.} & \multirow{2}{*}{$\begin{array}{l}\text { Kebiasaan Memakai } \\
\text { APD }\end{array}$} & Tidak Memakai APD & 28 & 50,00 \\
\hline & & Memakai APD & 28 & 50,00 \\
\hline \multirow[t]{2}{*}{4.} & \multirow[t]{2}{*}{ Intensitas Kebisingan } & $\geq 85 \mathrm{~dB}$ & 20 & 35,70 \\
\hline & & $<85 \mathrm{~dB}$ & 36 & 64,30 \\
\hline \multirow[t]{2}{*}{5.} & \multirow[t]{2}{*}{$\begin{array}{l}\text { Gangguan } \\
\text { Pendengaran }\end{array}$} & $\begin{array}{l}\text { Ada Gangguan } \\
\text { Pendengaran }\end{array}$ & 21 & 37,50 \\
\hline & & Normal & 35 & 62,50 \\
\hline
\end{tabular}

Hasil penelitian diperoleh distribusi variabel faktor yang berhubungan dengan gangguan pendengaran antara lain; sebanyak 73,20\% umur responden lebih dari 40 tahun; masa kerja lebih dari 20 tahun sebanyak 51,80\%; sebagian besar

responden $(50 \%)$ tidak menggunakan APD pada saat bekerja; sedangkan intensitas kebisingan di ruang produksi masih dibawah NAB 85 dB yaitu sebesar $64,30 \%$; dan sebagian besar pekerja tidak ada gangguan pendengaran yaitu $62,50 \%$.

Tabel 3. Faktor yang Berhubungan dengan Gangguan Pendengaran Pekerja di Industri Pengolahan Karet PT. X Kabupaten Seluma Tahun 2019

\begin{tabular}{|c|c|c|c|c|c|c|}
\hline \multirow{2}{*}{ No } & \multirow{2}{*}{ Variabel penelitian } & \multicolumn{2}{|c|}{ Gangguan Pendengaran } & \multirow[b]{2}{*}{$p$} & \multirow{2}{*}{ OR } & \multirow{2}{*}{$95 \% \mathrm{Cl}$} \\
\hline & & Ada Gangguan & Normal & & & \\
\hline 1. & $\begin{array}{l}\text { Umur Responden } \\
\geq 40 \text { Tahun } \\
<40 \text { Tahun }\end{array}$ & $\begin{array}{c}19(90,50 \%) \\
2(20 \%)\end{array}$ & $\begin{array}{l}22(62,90 \%) \\
13(37,10 \%)\end{array}$ & 0,050 & 5,61 & $\begin{array}{l}1,12- \\
28,09\end{array}$ \\
\hline 2. & $\begin{array}{l}\text { Masa Kerja } \\
\quad \geq 20 \text { Tahun } \\
<20 \text { Tahun }\end{array}$ & $\begin{array}{l}10(47,60 \%) \\
11(52,40 \%)\end{array}$ & $\begin{array}{l}19(54,30 \%) \\
11(45,70 \%)\end{array}$ & 0,836 & 0,766 & $\begin{array}{l}0,25- \\
2,26\end{array}$ \\
\hline 3. & $\begin{array}{l}\text { Pemakaian APD } \\
\text { Tidak Memakai } \\
\text { APD } \\
\text { Memakai APD }\end{array}$ & $\begin{array}{c}16(76,20 \%) \\
5(23,80 \%)\end{array}$ & $\begin{array}{l}12(34,30 \%) \\
23(65,70 \%)\end{array}$ & 0,006 & 6,133 & $\begin{array}{l}1,80- \\
20,83\end{array}$ \\
\hline 4. & $\begin{array}{l}\text { Intensitas } \\
\text { Kebisingan } \\
\quad \geq 85 \mathrm{~dB} \\
\quad<85 \mathrm{~dB}\end{array}$ & $\begin{array}{c}12(57,10 \%) \\
9(42,90 \%)\end{array}$ & $\begin{array}{c}8(22,90 \%) \\
27(77,10 \%)\end{array}$ & 0,021 & 4,50 & $\begin{array}{l}1,39- \\
14,50\end{array}$ \\
\hline
\end{tabular}

Hasil penelitian menunjukkan bahwa bahwa proporsi responden yang mempunyai gangguan pendengaran pada umur lebih dari 40 tahun sebesar 90,50\% lebih besar dibanding responden yang tidak mengalami gangguan pendengaran yaitu sebesar 62,90 $\%$; proporsi responden yang mempunyai gangguan pendengaran yang bekerja lebih dari 20 tahun sebesar 47,60\% lebih kecil dibanding responden yang tidak mengalami gangguan pendengaran sebesar 54,30 \%; proporsi responden yang mempunyai gangguan pendengaran yang tidak memakai APD sebesar 76,20\% lebih besar dibanding responden yang tidak mengalami gangguan pendengaran yaitu sebesar 34,30 \%; proporsi responden yang mempunyai gangguan pendengaran yang terpapar intensitas kebisingan lebih dari $85 \mathrm{~dB}$ sebesar 57,10 \% lebih besar dibanding responden yang yang tidak mengalami gangguan pendengaran yaitu sebesar 22,90 
\%. Variabel penelitian yang berhubungan

Kebisingan dengan nilai $\mathrm{p}$ masing-masing dengan gangguan pendengaran adalah umur, pemakaian APD dan Intensitas

Tabel 4.10:Hasil Analisis Regresi Logistik Fakor Risiko gangguan pendengaran

\begin{tabular}{llccccc}
\hline \multirow{2}{*}{ No } & \multirow{2}{*}{ Variabel } & \multirow{2}{*}{$\mathrm{B}$} & $P$ & $\mathrm{Exp}$ & \multicolumn{2}{c}{$95 \% \mathrm{CI}$} \\
\cline { 5 - 7 } & & & $(\mathrm{OR})$ & Lower & Upper \\
\hline 1. & Intensitas Kebisingan & $-2,599$ & 0,00 & 0,074 & 0,01 & 0,457 \\
& & 5 & & 2 & \\
\hline 2. & Pemakaian APD & $-2,712$ & 0,00 & 0,066 & 0,01 & 0,403 \\
& & & 3 & & 1 & \\
\hline 3. & Umur & $-2,198$ & 0,03 & 0,111 & 0,14 & 0,884 \\
& & 8 & & & \\
\hline
\end{tabular}

Constanta: 4,833

Hasil analisis multivariatpada tabel 4, dimasukkan dalam rumus persamaan regresi logistik maka diperoleh bahwa keterlibatan anak dalam bidang pertanian memiliki probabilitas terkena goiter sebesar $69,6 \%$

\section{PEMBAHASAN}

\section{Umur Responden dengan Gangguan Pendengaran}

Umur dapat menjadi salah satu faktor yang menyebabkan terjadinya gangguan pendengaran, utamanya pada umur 40 tahun ke atas karena pada umur tersebut terjadi penurunan pada beberapa alat indera manusia salah satunya presbiakusis. Semakin bertambah usia sebagian dari selsel rambut ini akan mati karena "tua". Karena itulah seseorang dapat menderita ketulian. Namun apabila seseorang mendapatkan tekanan kebisingan dengan intensitas tinggi secara kontinu untuk jangka waktu yang panjang, maka akan banyak sel-sel rambutnya yang menjadi mati ketika ia masih berumur muda. Apabila terdapat sejumlah sel-sel rambut yang mati, maka orang tersebut akan menderita kehilangan pendengaran

Hasil penelitian menunjukkan bahwa $90,50 \%$ responden yang mengalami gangguan pendengaran berumur lebih dari 40 tahun lebih besar dibanding responden yang tidak mengalami gangguan pendengaran yaitu sebesar $62,90 \%$. Hasil uji statistik dengan Chi Square diperoleh nilai p-value: 0,051 $(\mathrm{p}<0,05)$. Hasil uji ini menunjukkan bahwa ada hubungan yang bermakna antara umur dengan gangguan pendengaran. Nilai Odds Ratio (OR): 5,61 artinya responden yang berumur lebih dari 40 tahun mempunyai peluang 5,61 kali untuk mengalami gangguan pendengaran dibandingkan dengan responden yang berumur kurang dari 40 tahun

Hasil penelitian lainnya juga menunjukkan hasil yang sama, penelitian yang dilakukan oleh Hisma dkk (2014) pada pekerja di unit produksi Paving Block CV. Sumber Galian Makassar dengan hasil tabulasi silang antara umur dengan gangguan pendengaran menunjukkan 25 responden dengan kategori umur tua terdapat sebanyak 22 responden (88\%) yang mengalami gangguan pendengaran dan sebanyak tiga responden (12\%) yang tidak mengalami gangguan pendengaran. Berdasarkan lima belas jumlah responden dengan umur kategori muda terdapat dua responden (13.3\%) yang mengalami gangguan pendengaran dan tiga belas responden $(86.7 \%)$ yang tidak mengalami gangguan. ${ }^{7}$

Menurut Achmadi (2013), bahwa umur merupakan faktor yang tidak secara langsung mempengaruhi keluhan subjektif gangguan pendengaran akibat kebisingan namun pada usia di atas 40 tahun akan lebih mudah mengalami gangguan pendengaran dan rentan terhadap trauma akibat bising. 
Penurunan daya dengar secara alamiah yang diasumsikan mengakibatkan peningkatan ambang pendengaran $0.5 \mathrm{~dB}$ tiap tahun sejak usia 40 tahun $^{8}$.

\section{Masa Kerja dengan Gangguan Pendengaran}

Seorang pekerja memiliki masa kerja lebih lama mungkin lebih berisiko mengalami penyakit akibat kerja dibandingkan pekerja yang memiliki masa kerja yang lebih pendek, Jika semakin lama seorang pekerja berada di dalam ruangan yang bising maka semakin besar pula potensi bahaya yang akan diterima pekerja tersebut.

Hasil penelitian menunjukkan bahwa $47,60 \%$ responden yang mengalami gangguan pendengaran sudah bekerja selama lebih dari 20 tahun lebih dari 20 tahun sebesar lebih kecil dibanding responden yang tidak mengalami gangguan pendengaran sebesar 54,30 \%. Hasil uji statistik dengan Chi Square diperoleh nilai p-value: 0,836 ( $>0,05)$. Hasil uji ini menunjukkan bahwa tidak ada hubungan yang bermakna antara masa kerja dengan gangguan pendengaran.

Pada penelitian ini tidak adanya hubungan yang bermakna antara masa kerja dengan gangguan pendengaran, dikarenakan adanya jumlah cukup besar untuk masa kerja yang lebih dari 5 tahun dari 56 pekerja yang dijadikan sampel penelitian ini seluruhnya lebih dari 5 tahun. sebagian responden $(51,80 \%)$ sudah bekerja di PT X selama lebih dari 20 tahun. ${ }^{9}$

Penelitian ini sejalan dengan penelitian yang dilakukan oleh Kusumawati (Tahun 2012) menyimpulkan bahwa Tidak ada hubungan yang bermakna antara masa kerja dengan gannguan pendengaran dengan nilai $p$-value sebesar 0,967 dan diketahui dari 110 pekerja, sebanyak 28 pekerja dengan persentase $25,50 \%$ merupakan pekerja yang baru memiliki masa kerja kurang dari 1 tahun. ${ }^{10}$

Menurut Tarwaka (2014), mengatakan bahwa faktor masa kerja berpengaruh terhadap nilai ambang dengar tenaga kerja.
Hal ini salah satunya disebabkan oleh tingginya kejadian keluhan kesehatan yang dialami pekerja disebabkan karena tidak adanya system rotasi pekerja yang berlaku tiap lima tahunnya, sehingga masa kerja pekerja jadi lebih lama. Upaya tersebut bertujuan untuk mengurangi risiko terjadinya gangguan pendengaran maupun non pendengaran. ${ }^{11}$

\section{Pemakaian APD dengan Gangguan Pendengaran}

Penggunaan Alat Pelindung Diri (APD) merupakan langkah terakhir dalam hirarki pengendalian segala jenis bahaya, termasuk bahaya kebisingan. Sebelum itu banyak tahapan-tahapan yang dilakukan seperti menggunakan peralatan mesin dan peralatan kerja yang menimbulkan kebisingan yang lebih kecil atau pemberian shift tertentu bagi pekerja yang bekerja di lingkungan yang cukup bising. Namun hal ini belum dapat menetralisir potensi bahaya dari kebisingan. Maka dari itu penggunaan APD menjadi langkah terakhir untuk menetralisirnya.

Hasil penelitian menunjukkan bahwa $76,20 \%$ responden yang tidak memakai APD mengalami gangguan pendengaran, lebih besar dibanding responden yang tidak mengalami gangguan pendengaran yaitu sebesar 34,30\%. Hasil uji statistik dengan Chi Square diperoleh nilai $p$-value: 0,006 $(\mathrm{p}<0,05)$. Hasil uji ini menunjukkan bahwa ada hubungan yang bermakna antara pemakaian APD dengan gangguan pendengaran. Nilai Odds Ratio (OR): 6,13 artinya responden yang tidak memakai APD mempunyai peluang 6,13 kali untuk mengalami gangguan pendengaran dibandingkan dengan responden yang memakai APD.

Penggunaan Alat Pelindung Diri (APD) yaitu earmuff atau earplug mampu mengurangi efek kebisingan yang diterima oleh indera penggunanya, sehingga para pekerja yang menggunakan APD akan memiliki risiko atau potensi terkena bahaya akibat kebisingan yang lebih kecil 
dibandingkan para pekerja yang tidak menggunakan APD sama sekali.

Hasil ini sejalan dengan penelitian Hasbi Ibrahim (2016) pada pekerja produksi di PT Japfa Comfeed Indonesia, Tbk. dari 46 responden ada sekitar 28 orang (60.9\%) yang mengalami keluhan gangguan pendengaran akibat tidak menggunakan alat pelindung diri saat bekerja di tempat kerjanya dan sisanya yaitu 18 orang (39.1\%) tidak mengalami keluhan gangguan pendengaran. Hasil uji statistik dengan penrhitungan OR terhadap faktor risiko penggunaan APD pada tingkat kepercayaan $95 \%$ diperoleh nilai OR 2.27\%, menunjukkan bahwa orang yang tidak menggunakan APD saat bekerja, 2.27 kali berisiko terkena gangguan pendengaran dibandingkan dengan orang yang menggunakan APD saat bekerja. ${ }^{12}$

\section{Intensitas Kebisingan dengan Gangguan Pendengaran}

Pada dasarnya semakin tinggi kebisingan yang diterima seseorang maka risiko untuk terkena dampak dari kebisingan itu sendiri akan semakin besar pula. Intensitas kebisingan yang tinggi berdampak langsung pada kesehatan seserang bahkan secara langsung dapat merusak indera pendengaran. Semakin tinggi intensitas kebisingan di tempat kerja maka semakin besar pula potensi bahaya yang dapat ditimbulkan bagi pekerja. Intensitas bising yang melebihi Nilai Ambang Batas (NAB) dapat mengakibatkan gangguan pendengaran. Intensitas bising juga dapat mengakibakan pengaruh yang bersifat non auditoir atau pengaruh yang bukan terhadap pendengaran dan pengaruh audiotoir atau pengaruh terhadap pendengaran yang dapat berlangsung atau menetap.

Hasil penelitian menunjukkan bahwa $57,10 \%$ responden yang mengalami gangguan pendengaran terpapat intensitas kebisingan lebih dari $85 \mathrm{~dB}$ lebih besar dibanding responden yang yang tidak mengalami gangguan pendengaran yaitu sebesar 22,90\%. Uji statistik dengan $C h i$ Square diperoleh nilai p-value: 0,021 $(p<0,05)$. Hasil uji ini menunjukkan bahwa ada hubungan yang bermakna antara intensitas kebisingan dengan gangguan pendengaran. Hasil analisis diperoleh nilai Odds Ratio (OR): 4,50 artinya responden yang terpapar intensitas kebisingan lebih dari $85 \mathrm{~dB}$ mempunyai peluang 4,50 kali untuk mengalami gangguan pendengaran dibandingkan dengan responden yang terpapar intensitas kebisingan kurang dari $85 \mathrm{~dB}$.

Kehilangan pendengaran bukan saja akibat dari usia melainkan juga diakibatkan kebisingan yang sangat keras. Bising dengan intensitas yang melebihi $85 \mathrm{~dB}$ dapat merusak reseptor pendengaran di telinga dalam, yang mengalami kerusakan adalah organ corti untuk reseptor bunyi yang berfrekuensi $3000 \mathrm{~Hz}$ sampai dengan $6000 \mathrm{~Hz}$, dan yang paling berat kerusakannya adalah organ corti untuk reseptor bunyi yang berfrekuensi $4000 \mathrm{~Hz}$. Gejala yang ditimbulkan antara lain kurang pendengaran disertai dengan tinnitus.

Hal ini juga sejalan dengan penelitian Marisdayana R dkk (2016) pada karyawan PT. X dari 101 responden ada 41 responden yang mengalami ganguuan pendengaran dengan rincian, 33 responden $(54,1 \%)$ yang mengalami gangguan pendengaran akibat paparan bising melebihi $\mathrm{NAB}$ dan yang menderita gangguan pendengaran akibat paparan bising yang tidak melebihi NAB kebisingan ada sekitar 8 orang (20\%). Dari hasil uji statistik membuktikan ada hubungan yang signifikan antara intensitas paparan bising dengan gangguan pendengaran. $(p=0.001){ }^{13}$

\section{KESIMPULAN}

Variabel yang berhubungan dengan gangguan pendengaran pada pekerja di area proses produksi PT X adalah umur $p$-value: 0,051 ( $\mathrm{p}<0,05)$ nilai Odds Ratio (OR): 5,61; Pemakaian APD dengan nilai $p$-value: $0,006(\mathrm{p}<0,05)$ nilai Odds Ratio (OR) : 6,13 dan intensitas kebisingan dengan nilai $p$ - 
value: $0,021 \quad(\mathrm{p}<0,05)$ nilai Odds Ratio (OR): 4,50

\section{UCAPAN TERIMAKASIH}

Kami mengucapkan terimakasih Unit Penelitian Poltekkes Kemenkes Bengkulu yang telah memfasilitasi penelitian ini. Sehingga penelitian ini dapat terlaksana dengan baik.

\section{DAFTAR PUSTAKA}

1 Suma'mur, PK.. Higiene Perusahaan dan Keselamatan Kerja. Jakarta: Sagung Seto, 2013

2 Jumali, Sumadi, Andriani S, Subhi M, Suprijanto D, Handayani WD, et al. Prevalensi dan Faktor Risiko Tuli Akibat Bising pada Operator Mesin Kapal Feri. Jurnal Kesehatan Masyarakat Nasional. 2013, 7 (12)

3 World Health Organization (WHO),. Grades of Hearing Loss Impairment. 2015 Website: http://www.who.int/deafness/hearing im pairment grades/en/,

4 Arlinger S, Negative Consequences of Uncorrected Hearing Loss-A Review. Int J Audiol. 2003,Jul; 42 Suppl 2:2.

5 Mukono J, Epidemiologi Lingkungan Enviromental Epidemiology. Surabaya: Airlangga Univerisity Press, 2002

6 Soepardi E, Iskandar N. (eds), Buku Ajar IImu Kesehatan Telinga Hidung Tenggorok (Edisi ke-5). Jakarta: BP FK UI, 2003.

7 Hisma, Hubungan Kebisingan dengan Gangguan Pendengaran Pada Pekerja di Unit Produksi Paving Block CV. Sumber Galian Makassar: Universitas Hasanuddin, 2014

8 Achmadi, Upaya Kesehatan Kerja Sektor Informal di Indonesia. Jakarta: Depkes RI, 2013.
9 Sari, D. Pemetaan Tingkat Kebisingan dan Hubungan Lama Pemaparan Terhadap Gangguan Pendengaran pada PT PLN (Persero) Sektor Mahakam Samarinda. Fisika Mulawarman, 2012 Vol 8 (No 1).

10 Kusumawati, Hubungan Tingkat Kebisingan Di Lingkungan Kerja Dengan Kejadian Gangguan Pendengaran Pada Pekerja di PT X 2012. Skripsi. Depok:UI, 2012.

11 Tarwaka, Bakri, S., Sudiadjeng, L, Ergonomi Untuk Keselamatan, Kesehatan Kerja dan Produktivitas. Surakarta: Uniba Press, 2014.

12 Ibrahim H, Basri S, Hamzah Z. FaktorFaktor Yang Berhubungan Dengan Keluhan Gangguan Pendengaran Pada Tenaga Kerja Bagian Produksi PT. Japfa Comfeed Indonesia, Tbk Unit Makassar. Al- Sihah: Public Health Science Journal 2016; 8(2):121-129.

13 Marisdayana $R$, Suhartono, Nurjazuli. Hubungan Intensitas Paparan Bising Dan Masa Kerja Dengan Gangguan Pendengaran Pada Karyawan PT.X. Jurnal Kesehatan Lingkungan Indonesia. 2016; 15(1):22-27 